\title{
Upaya Meningkatkan Kompetensi Guru Menggunakan Media Pembelajaran ICT melalui Supervisi dengan Teknik Individual di Sekolah Dasar
}

\author{
S Rusmiyati* \\ ${ }^{1}$ SDN 1Kalinanas, Japah, Blora. Dinas Pendidikan Kabupaten Blora Propinsi Jawa \\ Tengah. Desa Kalinanas Kecamatan Japah Kabupaten Blora 58257, Indonesia \\ *srirusmiyati0@gmail.com
}

\begin{abstract}
The purpose of this study was to improve teacher competence in SD Negeri 1 Kalinanas in using ICT learning media. The study was conducted in SD Negeri 1 Kalinanas for \pm 5 months starting Friday, July 22, 2016 until Saturday, November 19, 2016. The subjects of this study were 9 teachers. Data collection is done through interviews, observation and documentation. From the interviews, the results show that it is important to use ICT learning media very well. The study was conducted in 2 cycles. In the pre cycle, the average score was 78 with a percentage of $53 \%$ achievement of all teachers in the research indicators for the use of ICT learning media, in the first cycle 88 average values were obtained with $69 \%$ achievement of all teachers in the research indicators of ICT learning media use, and in cycle II obtained an average value of 97 with a percentage of $88 \%$ achievement of all teachers in the research indicators of the use of ICT learning media. There has been an increase in teacher competency in the use of ICT learning media after being supervised with individual techniques by the principal of SD Negeri 1 Kalinanas.
\end{abstract}

\begin{abstract}
Abstrak. Tujuan penelitian ini adalah untuk meningkatkan kompetensi guru di SD Negeri 1 Kalinanas dalam menggunakan media pembelajaran ICT. Penelitian dilakukan di SD Negeri 1 Kalinanas selama \pm 5 bulan dimulai Jumat, 22 Juli 2016 sampai dengan Sabtu, 19 November 2016. Subjek penelitian ini adalah guru berjumlah 9 guru. Pengumpulan data dilakukan melalui wawancara, observasi dan dokumentasi. Dari wawancara diperoleh hasil bahwa menyatakan penting untuk menggunakan media pembelajaran ICT dengan sangat baik. Penelitian dilakukan sebanyak 2 siklus. Pada pra siklus diperoleh nilai rata-rata 78 dengan persentase $53 \%$ pencapaian seluruh guru dalam indikator penelitian penggunaan media pembelajaran ICT, pada siklus 1 diperoleh nilai rata-rata 88 dengan persentase $69 \%$ pencapaian seluruh guru dalam indikator penelitian penggunaan media pembelajaran ICT, dan pada siklus II diperoleh nilai rata-rata 97 dengan presentase $88 \%$ pencapaian seluruh guru dalam indikator penelitian penggunaan media pembelajaran ICT. Terjadi peningkatan kompetensi guru dalam penggunaan media pembelajaran ICT setelah dilakukan Supervisi dengan teknik Individual oleh kepala sekolah SD Negeri 1 Kalinanas.
\end{abstract}

Kata kunci: media pembelajaran ICT, kompetensi guru, Supervisi dengan teknik Individual

\section{Pendahuluan}

Penggunaan ICT pada pembelajaran akan membantu peserta didik dalam menumbuhkan minat, prestasi dan perubahan tingkah laku peserta didik. Jika seorang peserta didik ingin belajar maka ia akan cepat dapat belajar mengerti, mengingat dan mengamalkannya. Setiap pembelajaran akan menjadi siksaan dan tidak dapat memberi manfaat jika tidak disertai sifat terbuka bagi bahan pelajaran tersebut. 
Berdasarkan hasil penelitian pra siklus melalui supervisi dengan teknik individual yang dilakukan di SD Negeri 11 Kalinanas Kecamatan Japah Kabupaten Blora diperoleh hasil terhadap media pembelajaran ICT dengan indikator 1) Ketersediaan media pembelajaran ICT sebesar 63\%, 2) Keterampilan guru dalam menggunakan media ICT sebesar 63\%, 3) Frekuensi penggunaan media pembelajaran ICT sebesar 63\%,4) Kesesuaian antara materi dengan penggunaan ICT sebesar $63 \%$, 5) ICT sebagai alat bantu pembelajaran sebesar $50 \%$, 6) Peserta didik memanfaatkan ICT untuk mempresentasikan materi sebesar 50\%, 7) Pemanfaatan ICT dalam pembelajaran oleh guru sebesar $50 \%$, 8) Menjembatani permasalahan keterbatasan kemampuan daya serap peserta didik sebesar 38\%, dan 9) Pengaruh penggunaan ICT terhadap lingkungan sekitar sebesar 38\%.

Berdasarkan data tersebut dapat disimpulkan bahwa penggunaan media pembelajaran ICT dalam mengajar belum maksimal atau belum lengkap. Maka dari itu diperlukan supervisi dengan teknik individual untuk meningkatkan kemampuan guru dalam menyusun media pembelajaran ICT. Bukan hanya kemampuan guru dalam mengajar yang menentukan kualitas pendidikan tetapi media pembelajaran ICT seorang guru juga menentukan kualitas pendidikan. Oleh karena itu, teknologi informasi dan teknologi komunikasi adalah dua buah konsep yang tidak terpisah. Jadi ICT mengandung pengertian yang luas yaitu segala kegiatan yang terkait dengan pemrosesan, pengelolaan, pemindahan informasi antar media [1].

Kondisi tersebut tidak dapat dibiarkan begitu saja karena akan berdampak pada pengembangan karir bagi guru yang bersangkutan. Permasalahan tersebut perlu penanganan yang harus dilakukan oleh kepala sekolah dengan mengoptimalkan peranan sebagai supervisor. Konsep supervisi modern [2] sebagai berikut: "Supervision is assistance in the devolepment of a better teaching learning situation". Supervisi adalah bantuan dalam pengembangan situasi pembelajaran yang lebih baik. Rumusan ini mengisyaratkan bahwa layanan supervisi meliputi keseluruhan situasi belajar mengajar (goal, material, technique, method, teacher, student, an envirovment).Langkah penanganan yang dapat dilakukan oleh kepala sekolah adalah melalui kegiatan supervisi dengan teknik individual. Melalui kegiatan supervisi dengan teknik individual yang dilakukan oleh kepala sekolah, maka diharapkan kinerja guru akan semakin baik sehingga kemampuan profesional guru semakin berkembang pula. Hal ini sesuai dengan tujuan dari supervisi dengan teknik individual, yaitu bahwa supervisi dengan teknik individual adalah upaya meningkatkan kemampuan guru dalam rangka mewujudkan proses belajar peserta didik yang lebih baik melalui cara mengajar yang lebih baik [3].

Berdasarkan latar belakang di atas diperlukan solusi untuk menyelesaikannya, maka solusi tersebut adalah Menggunakan Media Pembelajaran ICT melalui Supervisi dengan Teknik Individual untuk meningkatkan kompetensi guru. Berorientasi dari latar belakang di atas maka rumusan masalah dari penelitian ini adalah Apakah dengan supervisi dengan teknik individual akan dapat meningkatkan kemampuan guru dalam menggunakan media pembelajaran ICT di SD Negeri 1 Kalinanas Kecamatan Japah Kabupaten Blora tahun pelajaran 2015/2016? Tujuan dari penelitian ini adalah untuk meningkatkan kemampuan guru dalam menggunakan media pembelajaran ICT melalui supervisi dengan teknik individual di SD Negeri 1 Kalinanas Kecamatan Japah Kabupaten Blora tahun pelajaran 2015/2016.

\section{Metode}

Metode yang digunakan dalam penelitian ini adalah metode deskriptif, dengan menyusun teknik persentase untuk melihat peningkatan yang terjadi dari siklus ke siklus Penelitian ini adalah penelitian tindakan sekolah yang dilaksanakan dalam 2 siklus. Dengan tahapan perencanaan, pelaksanaan, observasi dan refleksi. Yang menjadi subyek dalam PTS ini adalah guru-guru di SD Negeri I Kalinanas Kecamatan Japah Kabupaten Blora yang berjumlah 9 guru termasuk guru kelas dan guru mata pelajaran. Sumber data dalam PTS ini adalah dokumen media pembelajaran ICT yang sudah dibuat guru yang yang memuat indikator : 11) Ketersediaan media pembelajaran ICT, 2) Keterampilan guru dalam menggunakan media ICT, 3) Frekuensi penggunaan media pembelajaran ICT, 4) Kesesuaian antara materi dengan penggunaan ICT, 5) ICT sebagai alat bantu pembelajaran, 6) Peserta 
didik memanfaatkan ICT untuk mempresentasikan materi, 7) Pemanfaatan ICT dalam pembelajaran oleh guru, 8) Menjembatani permasalahan keterbatasan kemampuan daya serap peserta didik, dan 9) Pengaruh penggunaan ICT terhadap lingkungan sekitar. Teknik pengumpulan data dalam penelitian ini adalah wawancara, observasi, dan diskusi.

\section{Hasil dan Pembahasan}

Dari obbservasi sebelum diberikan tindaka, dapat dilihat tabel dibawah ini.

Tabel 1. Daftar Nilai Peningkatan Kemampuan Guru Dalam Menggunakan

Media pembelajaran ICT Sebelum Tindakan (Pra siklus)

\begin{tabular}{|c|c|c|c|c|c|c|c|c|c|c|c|c|}
\hline \multirow{2}{*}{ NO } & \multirow{2}{*}{ INDIKATOR } & \multicolumn{9}{|c|}{ NAMA RESPONDEN } & \multirow{2}{*}{ JUMLAH } & \multirow{2}{*}{ PERSENTASE } \\
\hline & & A & $\mathrm{B}$ & $\mathrm{C}$ & $\mathrm{D}$ & $\mathrm{E}$ & $\mathrm{F}$ & G & $\mathrm{H}$ & I & & \\
\hline 1 & $\begin{array}{l}\text { Ketersediaan media } \\
\text { pembelajaran ICT }\end{array}$ & 4 & 4 & 4 & 4 & 4 & 3 & 2 & 2 & 2 & 29 & $63 \%$ \\
\hline 2 & $\begin{array}{l}\text { Keterampilan guru dalam } \\
\text { menggunakan media ICT }\end{array}$ & 2 & 1 & 4 & 4 & 4 & 4 & 4 & 2 & 2 & 25 & $63 \%$ \\
\hline 3 & $\begin{array}{l}\text { Frekuensi penggunaan media } \\
\text { pembelajaran ICT }\end{array}$ & 2 & 2 & 3 & 4 & 4 & 4 & 4 & 4 & 4 & 31 & $63 \%$ \\
\hline 4 & $\begin{array}{l}\text { Kesesuaian antara materi } \\
\text { dengan penggunaan ICT }\end{array}$ & 4 & 4 & 4 & 4 & 1 & 2 & 4 & 2 & 2 & 27 & $63 \%$ \\
\hline 5 & $\begin{array}{l}\text { ICT sebagai alat bantu } \\
\text { pembelajaran }\end{array}$ & 4 & 4 & 3 & 2 & 4 & 4 & 1 & 2 & 2 & 26 & $50 \%$ \\
\hline 6 & $\begin{array}{l}\text { Peserta didik memanfaatkan } \\
\text { ICT untuk mempresentasikan } \\
\text { materi }\end{array}$ & 2 & 4 & 4 & 4 & 3 & 4 & 2 & 1 & 1 & 25 & $50 \%$ \\
\hline 7 & $\begin{array}{l}\text { Pemanfaatan ICT dalam } \\
\text { pembelajaran oleh guru }\end{array}$ & 4 & 4 & 2 & 4 & 2 & 2 & 3 & 4 & 4 & 29 & $50 \%$ \\
\hline 8 & $\begin{array}{l}\text { Menjembatani permasalahan } \\
\text { keterbatasan kemampuan daya } \\
\text { serap peserta didik }\end{array}$ & 2 & 2 & 4 & 1 & 1 & 4 & 4 & 3 & 3 & 24 & $38 \%$ \\
\hline 9 & $\begin{array}{l}\text { Pengaruh penggunaan ICT } \\
\text { terhadap lingkungan sekitar }\end{array}$ & 2 & 4 & 2 & 3 & 2 & 4 & 2 & 4 & 4 & 27 & $38 \%$ \\
\hline & JUMLAH & 26 & 29 & 30 & 30 & 25 & 31 & 26 & 24 & 24 & & \\
\hline & NILAI & 72 & 81 & 83 & 83 & 69 & 86 & 72 & 67 & 67 & 76 & $53 \%$ \\
\hline & KETERANGAN & $\mathrm{BM}$ & $\mathrm{M}$ & M & M & $\mathrm{BM}$ & M & $\mathrm{BM}$ & $\mathrm{BM}$ & & & \\
\hline
\end{tabular}

Berdasarkan table di atas maka dapat digambarkan ke dalam grafik seperti di bawah ini :

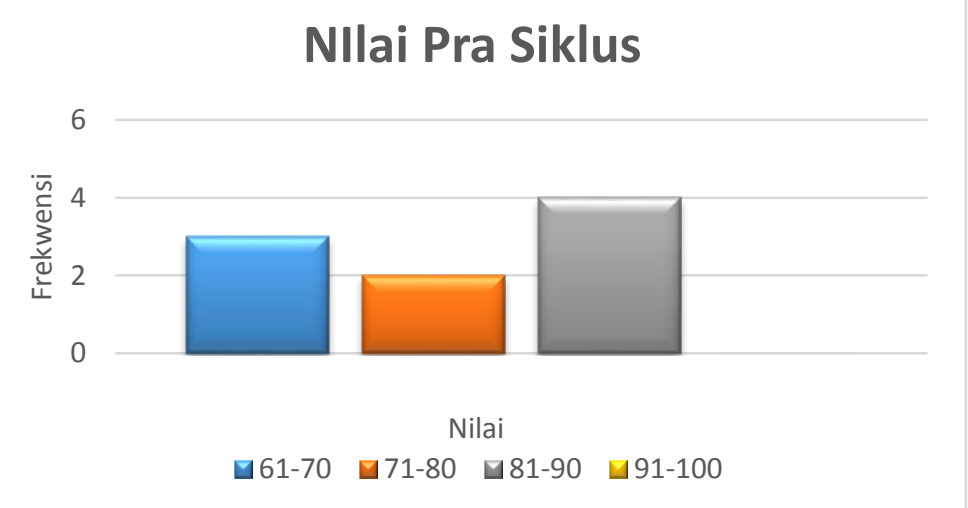

Gambar 1.Grafik Nilai Peningkatan Kemampuan Guru Dalam Menggunakan Media pembelajaran ICT Sebelum Tindakan (Pra Siklus) 
Dari penilaian peningkatan kemampuan guru dalam menggunakan media pembelajaran ICT yang dilakukan sebelum pelaksanaan siklus (pra siklus) diketahui bahwa hasilnya masih sangat rendah terbukti dari data perolehan di atas. Guru yang memperoleh nilai $61-70$ ada 3 0rang, atau $33 \%$. Yang memeroleh $71-80$ ada 2 orang atau $22 \%$, dan yang memperoleh $81-90$ ada 4 orang atau $45 \%$. Sedangkan yang memperoleh nilai 91-100 tidak ada. berikut

Pada siklus 1 terdapat peningkatan nilai kompetensi guru. Hal ini dapat dilihat pad tabel

Tabel 2. Nilai peningkatan kemamuan Guru dalam menggunakan edia Pembelajaran ICT Siklus 1

\begin{tabular}{|c|c|c|c|c|c|c|c|c|c|c|c|c|}
\hline \multirow{2}{*}{ NO } & \multirow{2}{*}{ INDIKATOR } & \multicolumn{8}{|c|}{ NAMA RESPONDEN } & & \multirow{2}{*}{ JUMLAH } & \multirow{2}{*}{$\begin{array}{l}\text { PERSEN- } \\
\text { TASE }\end{array}$} \\
\hline & & $\mathrm{A}$ & $\mathrm{B}$ & $\mathrm{C}$ & $\mathrm{D}$ & $\mathrm{E}$ & $\mathrm{F}$ & G & $\mathrm{H}$ & I & & \\
\hline 1 & $\begin{array}{l}\text { Ketersediaan media } \\
\text { pembelajaran ICT }\end{array}$ & 4 & 4 & 4 & 4 & 4 & 4 & 2 & 2 & 2 & 28 & $75 \%$ \\
\hline 2 & $\begin{array}{l}\text { Keterampilan guru dalam } \\
\text { menggunakan media ICT }\end{array}$ & 4 & 2 & 4 & 4 & 4 & 4 & 4 & 2 & 2 & 28 & $75 \%$ \\
\hline 3 & $\begin{array}{l}\text { Frekuensi penggunaan media } \\
\text { pembelajaran ICT }\end{array}$ & 2 & 4 & 4 & 4 & 4 & 4 & 4 & 4 & 4 & 30 & $83 \%$ \\
\hline 4 & $\begin{array}{l}\text { Kesesuaian antara materi } \\
\text { dengan penggunaan ICT }\end{array}$ & 4 & 4 & 4 & 4 & 2 & 3 & 4 & 4 & 4 & 23 & $63 \%$ \\
\hline 5 & $\begin{array}{l}\text { ICT sebagai alat bantu } \\
\text { pembelajaran }\end{array}$ & 4 & 4 & 4 & 4 & 4 & 4 & 2 & 2 & 2 & 28 & $75 \%$ \\
\hline 6 & $\begin{array}{l}\text { Peserta didik memanfaatkan } \\
\text { ICT untuk mempresentasikan } \\
\text { materi }\end{array}$ & 2 & 3 & 3 & 3 & 4 & 4 & 2 & 1 & 1 & 23 & $63 \%$ \\
\hline 7 & $\begin{array}{l}\text { Pemanfaatan ICT dalam } \\
\text { pembelajaran oleh guru }\end{array}$ & 4 & 4 & 2 & 4 & 2 & 3 & 4 & 4 & 4 & 23 & $63 \%$ \\
\hline 8 & $\begin{array}{l}\text { Menjembatani permasalahan } \\
\text { keterbatasan kemampuan daya } \\
\text { serap peserta didik }\end{array}$ & 4 & 4 & 4 & 2 & 2 & 4 & 4 & 3 & 3 & 23 & $63 \%$ \\
\hline 9 & $\begin{array}{l}\text { Pengaruh penggunaan ICT } \\
\text { terhadap lingkungan sekitar }\end{array}$ & 2 & 4 & 4 & 4 & 2 & 4 & 2 & 4 & 4 & 23 & $63 \%$ \\
\hline & JUMLAH & 30 & 34 & 34 & 34 & 28 & 34 & 28 & 26 & 26 & & \\
\hline & NILAI & 83 & 94 & 94 & 94 & 78 & 94 & 78 & 72 & 72 & 84 & $69 \%$ \\
\hline & KETERANGAN & $\mathrm{M}$ & $\mathrm{M}$ & M & M & $\mathrm{M}$ & $\mathrm{M}$ & $\mathrm{M}$ & $\mathrm{BM}$ & & & \\
\hline
\end{tabular}

Berdasarkan tabel di atas, dapat digambarkan dengan grafik di bawah ini.

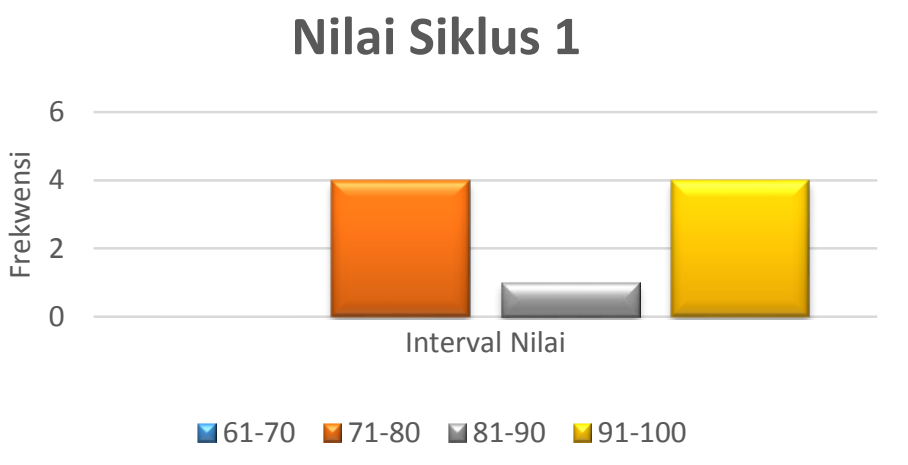

Gambar 2.Grafik Nilai Peningkatan Kemampuan Guru Dalam Menggunakan Media pembelajaran ICT Sebelum Tindakan (Siklus 1) 
Berdasarkan data yang diperoleh pada siklus 1 dapat dikatakan bahwa terjadi peningkatan untuk masing-masing indikator penelitian dari kegiatan pra siklus ke siklus 1 . Dan dari hasil penilaian yang dilakukan diperoleh data rata-rata prosentase untuk semua indikator media pembelajaran ICT adalah $69 \%$ dan rata-rata hasil nilai guru adalah 84 .

Hasil observasi yang dilakukan pada siklus II diperoleh data masing-masing indikator penelitian.

Tabel 3.Daftar Nilai Peningkatan Kemampuan Guru Dalam Menggunakan

Media pembelajaran ICT Siklus II

\begin{tabular}{|c|c|c|c|c|c|c|c|c|c|c|c|c|}
\hline \multirow{2}{*}{ NO } & \multirow{2}{*}{ INDIKATOR } & \multicolumn{9}{|c|}{ NAMA RESPONDEN } & \multirow{2}{*}{ JUMLAH } & \multirow{2}{*}{$\begin{array}{l}\text { PROS } \\
\text { ENTA } \\
\text { SE }\end{array}$} \\
\hline & & A & B & $\mathrm{C}$ & $\mathrm{D}$ & $\mathrm{E}$ & $\mathrm{F}$ & $\mathrm{G}$ & $\mathrm{H}$ & I & & \\
\hline 1 & $\begin{array}{l}\text { Ketersediaan media } \\
\text { pembelajaran ICT }\end{array}$ & 4 & 4 & 4 & 4 & 4 & 4 & 4 & 4 & 4 & 32 & $100 \%$ \\
\hline 2 & $\begin{array}{l}\text { Keterampilan guru dalam } \\
\text { menggunakan media ICT }\end{array}$ & 4 & 4 & 4 & 4 & 4 & 4 & 4 & 4 & 4 & 32 & $100 \%$ \\
\hline 3 & $\begin{array}{l}\text { Frekuensi penggunaan media } \\
\text { pembelajaran ICT }\end{array}$ & 4 & 4 & 4 & 4 & 4 & 4 & 4 & 4 & 4 & 32 & $100 \%$ \\
\hline 4 & $\begin{array}{l}\text { Kesesuaian antara materi } \\
\text { dengan penggunaan ICT }\end{array}$ & 4 & 4 & 4 & 4 & 3 & 4 & 4 & 4 & 4 & 31 & $88 \%$ \\
\hline 5 & $\begin{array}{l}\text { ICT sebagai alat bantu } \\
\text { pembelajaran }\end{array}$ & 4 & 4 & 4 & 4 & 4 & 4 & 4 & 4 & 2 & 30 & $88 \%$ \\
\hline 6 & $\begin{array}{l}\text { Peserta didik memanfaatkan } \\
\text { ICT untuk mempresentasikan } \\
\text { materi }\end{array}$ & 4 & 4 & 4 & 4 & 4 & 4 & 4 & 4 & 2 & 30 & $88 \%$ \\
\hline 7 & $\begin{array}{l}\text { Pemanfaatan ICT dalam } \\
\text { pembelajaran oleh guru }\end{array}$ & 4 & 4 & 3 & 4 & 3 & 4 & 4 & 4 & 4 & 30 & $75 \%$ \\
\hline 8 & $\begin{array}{l}\text { Menjembatani permasalahan } \\
\text { keterbatasan kemampuan } \\
\text { daya serap peserta didik }\end{array}$ & 4 & 4 & 4 & 3 & 3 & 4 & 4 & 4 & 4 & 30 & $75 \%$ \\
\hline 9 & $\begin{array}{l}\text { Pengaruh penggunaan ICT } \\
\text { terhadap lingkungan sekitar }\end{array}$ & 4 & 4 & 4 & 4 & 3 & 4 & 3 & 3 & 4 & 30 & $75 \%$ \\
\hline & JUMLAH & 36 & 36 & 35 & 35 & 32 & 36 & 35 & 35 & 32 & & \\
\hline & NILAI & 100 & 100 & 97 & 97 & 89 & 100 & 97 & 97 & 89 & 97 & $88 \%$ \\
\hline & KETERANGAN & $\mathrm{M}$ & $\mathrm{M}$ & $M$ & $\mathrm{M}$ & M & $\mathrm{M}$ & $\mathrm{M}$ & $\mathrm{M}$ & $\mathrm{M}$ & & \\
\hline
\end{tabular}

Berdasarkan tabel 3. di atas maka dapat digambarkan ke dalam grafik seperti di bawah ini :

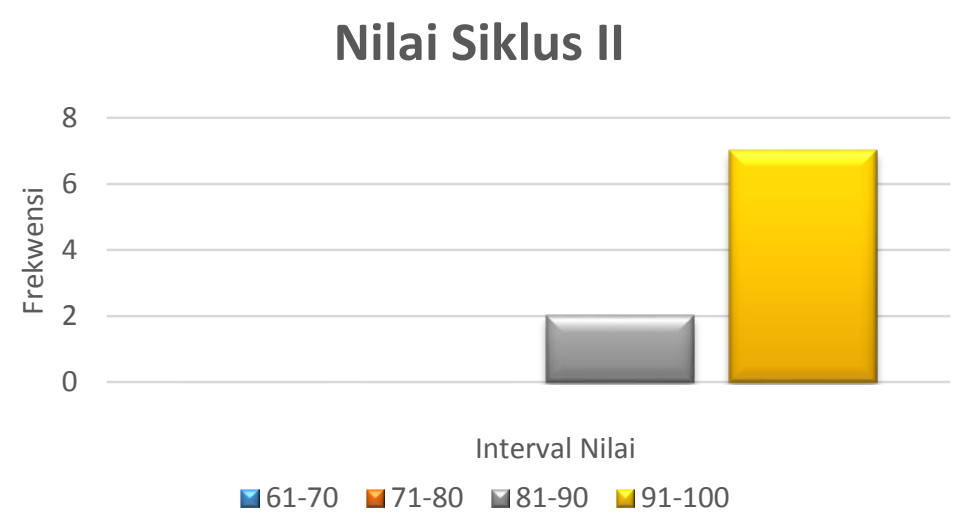

Gambar 4.Grafik Nilai Peningkatan Kemampuan Guru Dalam Menggunakan Media pembelajaran ICT Siklus II 
Berdasarkan data dari pra siklus, siklus I, dan siklus II dapat diketahui bahwa setiap siklus mengalami peningkatan untuk masing-masing indikator komponen pelaksanaan media pembelajaran ICT yaitu sebesar $75 \%$. Dan dari data akhir yang diperoleh dari siklus II ratarata prosentase kemampuan guru dalam menggunakan media pembelajaran ICT di SD Negeri 1 Kalinanas adalah 99 dengan prosentase 99\% sudah memenuhi indikator keberhasilan yaitu sebesar $75 \%$. Untuk lebih jelasnya dapat dilihat pada tabel 4.7 .

Tabel 4.

Perbandingan Ketuntasan Pra Siklus, Siklus I Dan Siklus II

\begin{tabular}{|l|c|c|c|}
\hline INTERVAL NILAI & PRA SIKLUS & SIKLUS 1 & SIKLUS II \\
\hline $61-70$ & 3 & 0 & 0 \\
\hline $71-80$ & 2 & 4 & 0 \\
\hline $81-90$ & 4 & 1 & 2 \\
\hline $91-100$ & 0 & 4 & 7 \\
\hline
\end{tabular}

Berdasarkan tabel 4. di atas maka dapat digambarkan ke dalam grafik seperti di bawah ini :

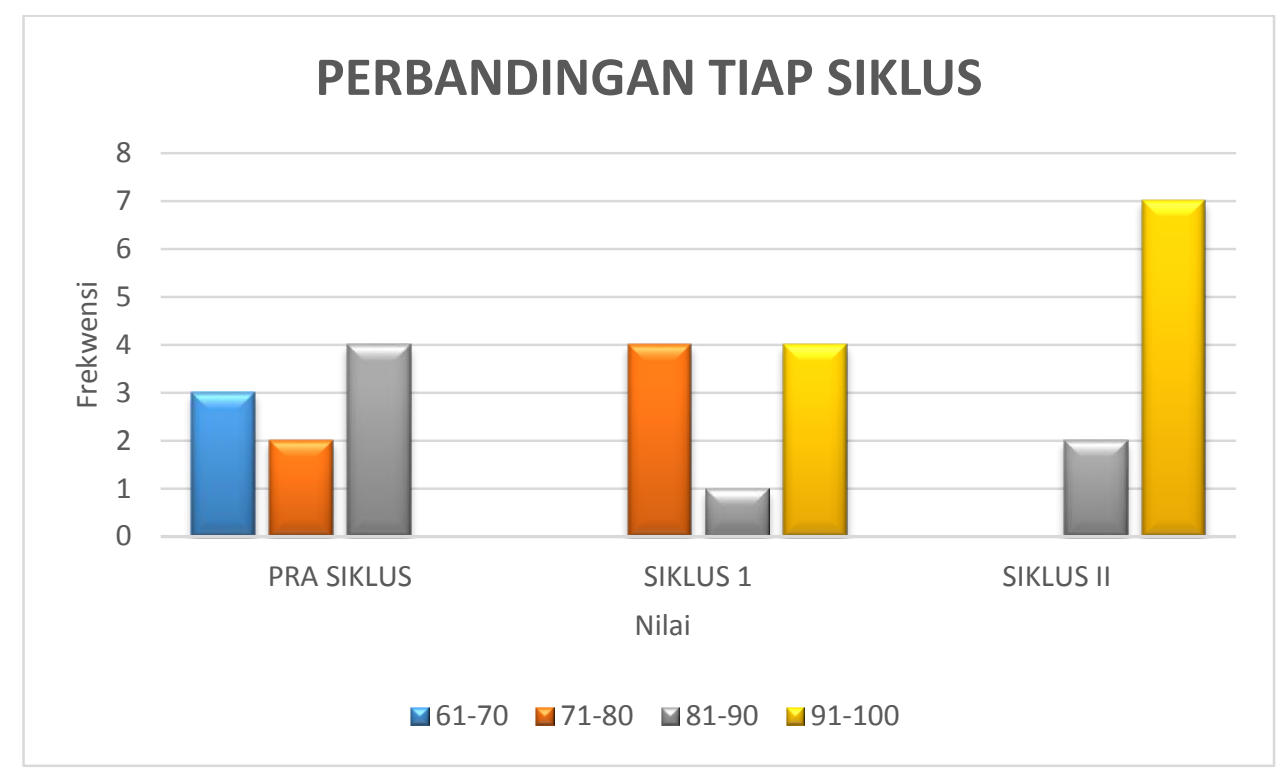

Gambar 4.4. Grafik Perbandingan Ketuntasan Pra Siklus, Siklus I Dan Siklus II

Dari data yang diperoleh dari pra siklus, siklus I, dan siklus II dapat disimpulkan bahwa terjadi peningkatan kemampuan guru dalam menggunakan media pembelajaran ICT di SD Negeri 1 Kalinanas pada tahun 2016/2017. Hal ini dikarenakan penggunaan supervisi dengan teknik individual yang dilakukan oleh Kepala Sekolah terhadap para guru.

\section{Kesimpulan}

Berdasarkan hasil Penelitian Tindakan Sekolah (PTS) dapat disimpulkan bahwa supervisi dengan teknik individual dapat meningkatkan motivasi guru dalam menggunakan media pembelajaran ICT dengan lengkap. Guru menunjukkan keseriusan dalam memahami dan menggunakan media pembelajaran ICT apalagi setelah mendapatkan bimbingan pengembangan/ penyusunan media pembelajaran ICT dari peneliti. Informasi ini peneliti peroleh dari hasil pengamatan pada saat mengadakan wawancara dan bimbingan pelaksanaan media pembelajaran ICT kepada para guru. Supervisi dengan teknik individual dapat meningkatkan kemampuan guru dalam menggunakan media pembelajaran ICT. Hal itu dapat dibuktikan dari hasil observasi /pengamatan yang memperlihatkan bahwa terjadi peningkatan kemampuan guru dalam menggunakan media pembelajaran ICT dari pra siklus ke siklus II . Pada pra siklus nilai rata-rata 
komponen media pembelajaran ICT adalah 78 dengan prosentase $53 \%$, siklus I nilai rata-rata komponen media pembelajaran ICT adalah 88 dengan prosentase $69 \%$ dan pada siklus II 97 dengan prosentase $88 \%$. Jadi, terjadi peningkatan dari masing-masing siklus dan pada tiap-tiap indikator.

\section{Referensi}

[1] Abdurrahma, Liliasari, A.Rusli, dan Bruce Waldrip. 2011. Implementasi Pembelajaran Multi Representasi untuk Peningkatan Penguasaan Konsep Fisika Kuantum. Jurnalis Pendidikan Carawala Pendidikan. Yogyakarta: LPM UNY

[2] Kimball, Wiles.1976. Introduction to Educational Administration Boston. Allyn and Baccon, Inc 